\title{
The Effect of Learning Models and Learning Styles on Social Science Learning Outcomes of Arrahman Percut Students
}

\author{
Lili Nur Indah Sari ${ }^{1}$, Abdul Muin Sibuea ${ }^{2}$, Samsidar Tanjung ${ }^{3}$ \\ ${ }^{1}$ Postgraduate Program in Education Technology, Universitas Negeri Medan, Indonesia \\ ${ }^{1,2}$ Universitas Negeri Medan, Indonesia \\ leepunyalif@gmail.com
}

\begin{abstract}
This study aims (1) to determine the differences in social studies learning outcomes taught by the Two Stay Two Stray (TSTS) learning model which is higher than the social studies learning outcomes with the Problem Based Learning model. (2) To find out the differences in social studies learning outcomes of students who have a higher visual learning style than the social studies learning outcomes of students who have a kinesthetic learning style. (3) To determine the interaction between learning models and student learning styles in influencing the social studies learning outcomes of private students, Ar Rahman Percut. The population of this study was 122 students of class VII-A and VII-B of Ar Rahman Percut Private Middle School. Samples were taken by cluster rondom sampling. The sample used in this study was 63 students. The selected sample is classVII-A and class VII-B. The instrument used was a multiple choice test, amounting to 30 items and a learning style questionnaire. The data were analyzed at the significant level $=0.05$, followed by the Scheffe further test after the normality and homogeneity tests. The results showed that, (1) There are differences in social studies learning outcomes, where the social studies learning outcomes with the Two Stay Two Stray (TSTS) learning model are higher than the social studies learning outcomes with the Problem Based Learning model with Fcount 8,70> Ftable 4.00, (2) There are differences in student social studies learning outcomes, where the social studies learning outcomes of students who have a visual learning style from the social studies learning outcomes of students who have a kinesthetic learning style with Fcount 5.01> Ftable 4.00, (3) There is an interaction between the learning model and the learning style of the students' social studies learning outcomes Fcount 5.20> Ftable 4.00.
\end{abstract}

Keywords two stay two stray (TSTS;) problem based learning; visual and kinesthetic learning

\section{Introduction}

The success of educators or teachers in the learning process is largely determined by the extent to which they understand the characteristics of their students. The ability of educators in this case is very important, namely how educators are able to identify the learning character of each student. The differences in learning characters have an effect on how students learn in achieving their learning outcomes. One of the characters possessed by students is the learning style. A person's learning style is a combination of how he absorbs, and then organizes and processes information. Knowing these different learning styles has helped teachers everywhere approach nearly all students simply by conveying information in different styles (Abdurrahman and Mulyono, 2012). 
Every individual has a different learning style. Not everyone follows the same way. Each of them shows a difference, but the researchers can classify them. Learning style is closely related to a person's personality, which is influenced by the nature, experience, education, and history of development (Mamo, 2009). The learning style referred to in this study is the method used by students in absorbing information or subject matter based on the sensory preference approach, namely the learning style that is carried out by entering information into the brain through their sensory modalities.

In general, there are three types of student learning (1) visual, where in learning, this type of student learns more easily by seeing or observing, (2) auditory, where students learn more easily by listening, and (3) kinesthetic, where in student learning is easier to learn by practicing (Utami, 2015). These different student learning styles can affect student learning outcomes, because learning styles are considered the most effective way by someone to process information so as to get maximum results.

Based on the research journal conducted Hartati, L (2015) entitled the effect of learning methods and student learning styles on social studies learning outcomes at State Junior High Schools in Yogyakarta, it shows that there is an influence between learning styles on students' social studies learning outcomes. Another research that also supports is Sudjana (2009) entitled the effect of student learning styles and attitudes on social studies learning outcomes with the results of research having a strong influence between learning styles and student attitudes towards student learning outcomes in social studies.

Learning outcomes are the abilities possessed by students after receiving their learning experiences (Ellis, 2003). Learning outcomes cannot be separated from the learning process itself. Learning is not just memorizing, but a mental process that occurs within a person in constructing the knowledge he gets. Simanjuntak (2020) stated that the level of learning outcomes obtained by students is influenced by the ability of teachers to manage learning evenly according to the educational background of the teacher. The achievement of the teaching and learning process is very dependent on the role of the teacher in learning activities in the classroom. One of the subjects that require students to construct their knowledge is Social Sciences (IPS). Learning is the process of changing behavior due to interactions among individuals and the environment (Resien, 2020). Learning according to Rusman in Utomo (2020) is a system, which consists of various components that are interconnected with one another. These components include: objectives, materials, methods, and evaluation. The purpose of social studies learning is to develop the potential of students to be able to adapt and be sensitive to social problems that occur in society, to have a positive mental attitude towards correcting any imbalances that occur, and to be skilled in overcoming any problems that occur daily, both that befall themselves and those that happen society (Muzaini, 2015).

Social studies learning will be optimal if students are actively involved in understanding the concept of learning, therefore it is necessary to teach the presentation and atmosphere of social studies learning that is effective and provokes students' curiosity in learning. This trait is very useful as motivation for students to continue to increase their knowledge.Social studies learning in schools generally uses the following order of presentation: (1) theory is taught, (2) examples of social conditions are given, and (3) exercises or questions are given. This kind of learning is commonly referred to as conventional learning (Lie, 2002). Learning patterns like this cause teachers to dominate learning more, while students are only good listeners and note takers. This problem has been attempted to be overcome, but the results are still not significant, to improve the learning outcomes of class VII students of Ar Rahman Percut Private Middle School, a 
learning model is sought that encourages students to like social studies lessons, one of the learning models referred to is the Two Stay cooperative learning model. Two Stray (TSTS).

The TSTS learning model is a learning model that provides opportunities for groups to share results and information with other groups (Hamiddin, 2012). The application of the TSTS learning model provides opportunities for students to exchange ideas and build social skills such as asking questions and providing opportunities for students to study with other groups, so that student interactions will develop during the learning process. The implementation of the TSTS learning model can be used to improve student achievement (Kristianingsih, 2010). In line with that, the TSTS learning model facilitates students to express their desire to be active in understanding the material.

\section{Research Method}

This research was conducted at Ar Rahman Percut Private Junior High School. The research was conducted in the even semester of the 2020/2021 academic year, namely September 2020. This research was conducted in 8 meetings in social studies lessons.

The method used in this research is quasi experimental research with a $2 \times 2$ factorial research design. This design will compare the effect of the TSTS learning model with the Problem Based Learning model. TSTS learning model and problem-based learning as independent variables, social studies learning outcomes as the dependent variable and learning style as the moderator variable.

Table 1. Research Design

\begin{tabular}{|l|c|c|}
\hline \multirow{2}{*}{$\begin{array}{c}\text { Learning Style } \\
\text { (B) }\end{array}$} & \begin{tabular}{c} 
Learning Model (A) \\
\cline { 2 - 3 }
\end{tabular} & $\begin{array}{c}\text { Problem Based Learning } \\
\text { Model (A2) }\end{array}$ \\
\hline $\begin{array}{l}\text { Kinesthetic Learning Styles } \\
\text { (B1) }\end{array}$ & A1B1 & A2B1 \\
\hline Visual Learning Styles (B2) & A1B2 & A2B2 \\
\hline
\end{tabular}

The research design was carried out in several stages of this research including: (1) the experimental preparation stage, (2) the experiment implementation stage, (3) the final stage of the experiment.

1. Experiment Preparation Stage

Experimental preparation activities include: setting the learning implementation schedule according to the semester program on the syllabus, curriculum and education calendar for Ar Rahman Percut Private Junior High School, preparing learning materials, preparing lesson plans, compiling research data collection instruments such as measuring student social studies learning outcomes, carrying out tests on validity and reliability of research instruments. Researchers compiled an agenda for the implementation of the research carried out in semester 1 of the 2018/2019 academic year. This research was agreed upon in 8 meetings. One meeting in question is 2 hours of lessons or $2 \times 40$ minutes. Before the treatment is carried out in the research, there are several things that must be prepared, namely: (1) determining the experimental class which is taught with the TSTS learning model and the control class which is taught with the Problem Based Learning model. 
The determination of the experimental class and the control class was carried out by cluster random sampling and the two classes were assumed to be the same in terms of the level of thinking ability, (2) the teachers who were partners in this study were given instructions and explanations, especially to teachers who used the TSTS learning model and the Learning model. Based on problems, (3) the formulation of learning objectives and the scope of material to be achieved by students are the same as those poured into the learning plan that is adjusted to the model used and the time the treatment is carried out.

2. Experiment Implementation Stage

The teacher conducted research by implementing the TSTS learning model for the experimental group and the Problem Based Learning model in the control group. Every time learning activities will be carried out, discussions will be carried out with the teaching teacher for both the experimental class and the control class to emphasize the teacher's assignments according to the learning scenario. At the end of each learning activity there is always a discussion with the teaching teacher to get input about the implementation of the application of each learning model and after face to face in the two group's ends, each group is given a social studies learning outcome test to obtain data on student social studies learning outcomes.

3. Final Stage of Experiment,

The stages taken in implementing learning using the TSTS learning model are as follows:

a. Preliminary activities convey learning objectives and motivate students. The teacher must convince students why the material must be studied. Students must know the learning objectives that will be studied at each meeting. So that they have a target in following the learning.

b. The core activities include several stages, namely: (a) presenting information, (b) organizing students into study groups, (c) guiding study groups, (d) submitting questions

c. Closing activity, giving awards. The award provides positive feedback to groups / students for their success in the form of praise.

\section{Results and Discussion}

\subsection{Result}

Social studies learning outcomes of students who are taught with the TSTS learning model are higher than students who are taught with problem-based models after analyzing variance, the results of the calculation of the learning model data are obtained, where Fcount $=8.70$, while the Ftable value is $\mathrm{dk}=(1.62)$ and $\alpha=0.05$ is 4.00 . These results indicate that Fcount $=8.70>$ Ftable $=4.00$, so the null hypothesis $(\mathrm{Ho})$ is rejected and the alternative hypothesis (Ha) is accepted, thus the research hypothesis which states that the social studies learning outcomes of students who are taught with the TSTS model are higher than students who are taught with Problem Based Learning Model are proven.

Likewise, to determine differences in social studies learning outcomes between students who have visual learning styles and kinesthetic learning styles. Based on the results of hypothesis testing, the results of the calculation of learning style data are obtained, where Fcount $=5.01$, while the Ftable value with $\mathrm{dk}=(1.62)$ and $\alpha=0.05$ is 4.00. These results indicate that Fcount $=5.01>$ Ftable $=4.00$, so that the Zero Hypothesis (Ho) is rejected and the Alternative Hypothesis (Ha) is accepted, thus the research 
hypothesis states that the social studies learning outcomes of students who have a visual learning style are higher than students who have proven kinesthetic learning styles.

There was an interaction between learning models and student learning styles in influencing social studies learning outcomes seen from the hypothesis, the results of the calculation of the interaction data of learning models and learning styles were obtained, where Fcount $=5.20$ and Ftable value with $\mathrm{dk}=(1.62)$ and $\alpha=0.05$ is 4.00 . These results indicate that Fcount> Ftable (5.01> 4.00), so the Alternative Hypothesis (Ha) is accepted and the Zero Hypothesis (Ho) is rejected, meaning that there is an interaction between learning models and learning styles in influencing social studies learning outcomes. Thus the hypothesis which states that there is an interaction between learning models and learning styles in influencing social studies learning outcomes is proven.

Furthermore, with the interaction between the learning model variables and learning styles on social studies learning outcomes, it is necessary to provide an estimated graphic image that shows the interaction.

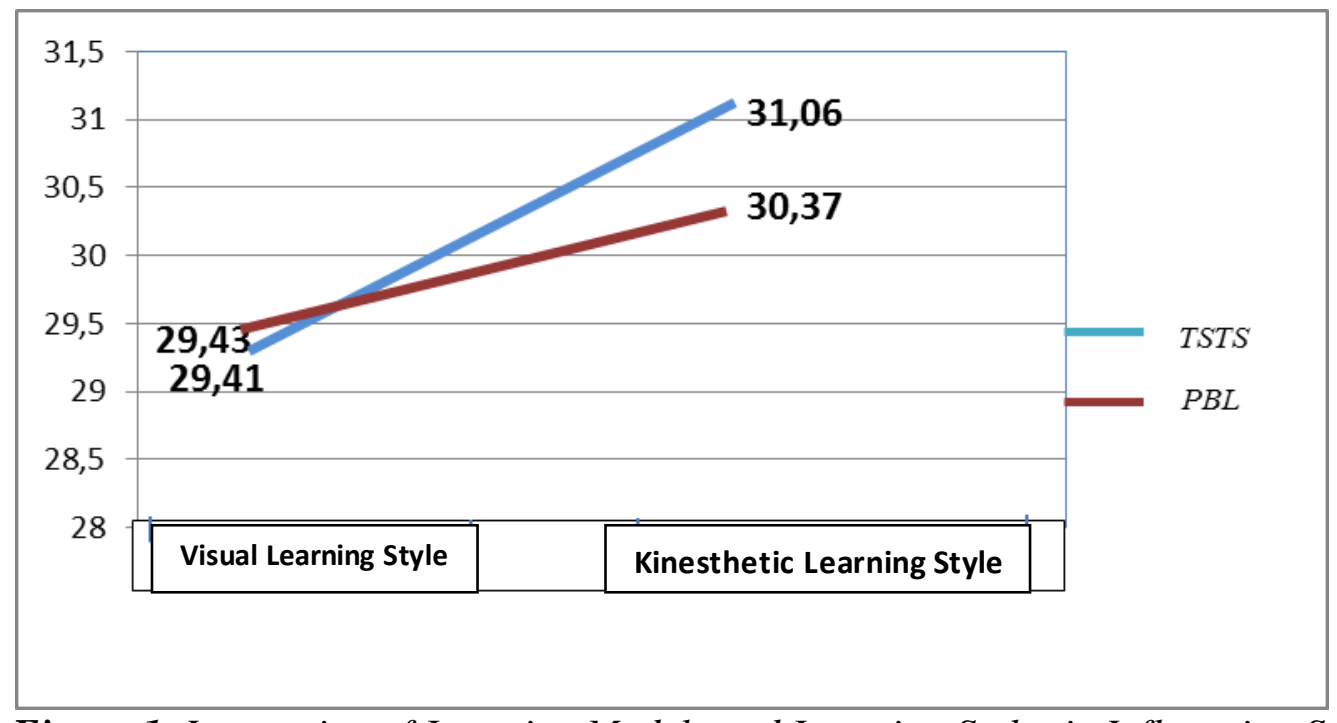

Figure 1. Interaction of Learning Models and Learning Styles in Influencing Student Social Studies Learning Outcomes

Based on the results of testing the third hypothesis which states that there is an interaction between learning models and learning styles in influencing social studies learning outcomes, it is necessary to carry out a further test (post hoc test), namely to find out the average learning outcomes of which samples are different. To see the form of interaction between learning models and learning styles in influencing social studies learning outcomes, further tests were carried out using the Scheefe test

Table 2. Summary of the Scheefe Test Calculation Results

\begin{tabular}{|c|c|c|c|}
\hline $\begin{array}{c}\text { Group scores being } \\
\text { compared }\end{array}$ & F count & $\begin{array}{c}\text { F table (3.62) } \\
\alpha=0.05\end{array}$ & Information \\
\hline$\mu \mathrm{A} 1 \mathrm{~B} 1$ with $\mu \mathrm{A} 2 \mathrm{~B} 1$ & 2.97 & 2.90 & Significant \\
\hline$\mu \mathrm{A} 1 \mathrm{~B} 1$ with $\mu \mathrm{A} 2 \mathrm{~B} 2$ & 3.03 & 2.90 & Significant \\
\hline$\mu \mathrm{A} 1 \mathrm{~B} 1$ with $\mu \mathrm{A} 1 \mathrm{~B} 2$ & 8,06 & 2.90 & Significant \\
\hline$\mu \mathrm{A} 2 \mathrm{~B} 1$ with $\mu \mathrm{A} 1 \mathrm{~B} 2$ & 0.046 & 2.90 & Not significant \\
\hline$\mu \mathrm{A} 2 \mathrm{~B} 1$ with $\mu \mathrm{A} 2 \mathrm{~B} 2$ & 6,844 & 2.90 & Significant \\
\hline$\mu \mathrm{A} 1 \mathrm{~B} 2$ with $\mu \mathrm{A} 2 \mathrm{~B} 2$ & 2.98 & 2.90 & Significant \\
\hline
\end{tabular}


Based on the results of the Scheefe test in Table 4:18 above, it can be seen that there are 6 (six) pairs of statistical hypotheses, namely:

1) From the results of the Scheefe Test above, it shows that Fcount> Ftable (2.97,> 2.90) so that it gives a decision to reject Ho. Thus the results of the study which stated that the average social studies learning outcomes of students who were taught with the TSTS Learning Model and visual learning styles were higher than the average social studies learning outcomes of students who were taught with the Problem Based learning model and visual learning styles were verified.

2) From the results of the Scheefe Test above, it shows that Fcount> Ftable (3.03> 2.90) so that it gives a decision to reject Ho. Thus the results of the study which stated that the average social studies learning outcomes of students who were taught with the TSTS Learning Model and visual learning styles were higher than the average social studies learning outcomes taught with the Problem Based Learning Model and the kinesthetic learning styles were proven.

3) From the results of the Scheefe test above, it shows that Fcount $>$ Ftable (8.06> 2.90) so that it gives a decision to reject Ho. Thus the results of the study which stated that the average social studies learning outcomes of students who were taught using the TSTS Learning Model and visual learning styles were higher than the average social studies learning outcomes of students taught with the TSTS Learning Model and the kinesthetic learning styles were verified.

4) From the results of the Scheefe Test above, it shows that Fcount $>$ Ftable $(0.046$ $<2.90)$ so that it gives a decision to accept Ho. Thus the results of the study which stated that the average social studies learning outcomes of students who were taught with the Problem Based Learning Model and visual learning styles were higher than the average social studies learning outcomes of students taught with the TSTS Learning Model and the kinesthetic learning styles were verified.

5) From the results of the Scheefe Test above, it shows that Fcount <Ftable (6.84 $<2.90)$ so that it gives a decision to reject Ho. Thus the results of the study which stated that the average social studies learning outcomes of students who were taught with problem-based learning models and visual learning styles were higher than the average social studies learning outcomes of students who were taught with problembased learning models and kinesthetic learning styles were proven.

6) From the results of the Scheefe Test above, it shows that Fcount <Ftable (2.98> 2.90) so that it gives a decision to accept Ho. Thus the results of the study which stated that the average social studies learning outcomes of students who were taught with the TSTS Learning Model and kinesthetic learning styles were higher than the average social studies learning outcomes of students taught with the Problem Based Model and the kinesthetic learning styles were not verified.

\subsection{Discussion}

The results of the first study indicate that the overall social studies learning outcomes for the group of students who use the blended learning model are higher than the group of students who use the problem-based learning model.. This is because students in the TSTS Learning Model group emphasize combining / combining conventional learning methods (face to face) with e-Learning methods. TSTS does not mean replacing conventional learning models in the classroom, but strengthens this learning model. because students not only listen to the teacher's lecture but do more learning activities such as observing, doing, demonstrating and so on. With TSTS learning, students have positioned themselves as 
active learner actors who understand their own needs and strive to achieve understanding of knowledge independently. Activities carried out by students during the Problem Based learning process will make students excited about the learning process. This is in line with Rovai and Jordan (2014) who argue that the TSTS Learning Model basically combines the advantages of learning that is done face-to-face (face to face learning) and virtually (elearning). Online learning or e-learning in TSTS is a natural extension of traditional classroom learning that uses face-to-face learning. In addition, according to Castle and McGuire (2010: 36), e-learning can improve the learning experience, because students can study anywhere and under any conditions as long as they are connected to the internet without having to take face-to-face learning. TSTS not only reduces the distance that has existed between students and teachers but also increases interaction between the two parties.

The results of the second study indicate that the average score of social studies learning outcomes of students who have visual learning styles is higher than students who have kinesthetic learning styles. This indicates that students who have a visual learning style are better able to understand social studies than students who have a kinesthetic learning style. According to Slameto (2010: 180) defineslearning styleas love and interest in one thing or something without being told. Learning style is very influential on a person's job. If a person puts a learning style in a lesson, he will carry out the task well, even if it takes up time so that he unconsciously works beyond his time limit and his health. Learning styles make students want to learn without being overwhelmed because they like the lesson. Activities that are in the style of learning someone are constantly paid attention to, accompanied by a sense of pleasure. Someone who has a learning style in a lesson, he will be interested in that lesson. Usually this person will always follow the development of information about the lesson.

The results of the third study indicate that there is an interaction between learning models and learning styles on learning outcomes IPS. When viewed from the average social studies learning outcomes in the group of students who have a visual learning style and are taught with the TSTS learning model, it is higher than the average learning outcomes of the group of students who have a visual learning style and are taught using the Problem Based Learning Model. Furthermore, the average social studies learning outcomes in the group of students who have a kinesthetic learning style and are taught with the TSTS learning model are lower than the average learning outcomes of groups of students who have a kinesthetic learning style and are taught using the Problem Based Learning Model. So, there is an increase in learning styles. This increase is because students can follow learning well, where students can solve the questions posed, there is a learning model that can foster students' enthusiasm for learning. Hardwinoto and Setiabudhi (2006: 111) state that students' learning styles towards learning will increase if they can understand and solve problems easily. A student who is able to get the best score in the test, this achievement based on the problem will give a sense of pride, with a sense of pride that is formed learning styles to achieve better grades, then this desire will spur the birth of a learning style model.

\section{Conclusion}

Based on the results of the research and discussion that has been stated previously, in this study it can be concluded that:

1. The social studies learning outcomes of students taught with the TSTS learning model are higher than students taught with the Problem Based learning model. 
2. Social studies learning outcomes of students who have a higher visual learning style than students who have a kinesthetic learning style.

3. There is an interaction between learning models and learning styles on social studies learning outcomes. Students who have a visual learning style get higher social studies learning outcomes when taught using the TSTS learning model rather than the Problem Based learning model, while students who have a kinesthetic learning style have higher learning outcomes if taught with the Problem Based learning model than the TSTS learning model.

\section{References}

Abdurrahman, Mulyono. (2012). Pendidikan Bagi Anak Berkesulitan Belajar:Teori, Diagnosis, dan Remediasinya. Jakarta: PT.Rineka Cipta.

Darmono, Al. (2012). Identifikasi Gaya Kognitif (Cognitive Style) Peserta Didik dalam Belajar. (online), Vol. 3, (http://ejounal.iaingawi.ac.id, diakses 15 November 2019).

Deporter B \& Hernacki M. 2015. Quantum Learning. Bandung. PT Mizan Pustaka

Ellis and Road (2003). Second Languange Acquisition. Hongkong: Oxford University Press

Hamiddin. (2012). Improving Students' Comprehension of Poems Using Two Stay Two Stray Strategy. Dalam jurnal Vidya Karya1 jilid 27. Nomor 1

Hartati, L. (2015). Gaya Belajar dan Sikap Siswa pada Pelajaran Matematika terhadap Hasil Belajar Matematika. Jurnal Formatif 3(3): 224-235

Kristianingsih, Dkk. (2010). Peningkatan Hasil Belajar Siswa Melalui Model Pembelajaran Two Stay Two Stray Dengan Metode Pictorial Riddle Padapokok Bahasan AlatAlat Optik Di SMP. Jurnal Pendidikan Fisika Indonesia 6 (2010) 10-13. Issn: 1693- 1246 Januari 2010.

Lie, A. (2002). Cooperative Learning. Jakarta : Gramedia Widiasarana Indonesia.

Marno dan M. Idris. (2009). Strategi dan Metode Pengajaran. Jogjakarta: Ar-Ruzz Media

Muzaini, Muhammad. (2015). Pengaruh Pendekatan Problem Posing Terhadap Prestasi BelajarMatematika Siswa dengan Memperhitungkan Gaya Siswa Kelas VII SMP Swasta Terakreditasi B di Kota Makassar. Makalah disajikan dalam Seminar Nasional IPS dan UNY, (online), (http://seminar.uny.ac.id, diakses 10 November 2019).

Resien, Sitompul, H., and Situmorang, H. (2020). The Effect of Blended Learning Strategy and Creative Thinking of Students on the Results of Learning Information and Communication Technology by Controlling Prior Knowledge. Budapest International Research and Critics in Linguistics and Education (BirLE) Journal Vol 3 (2): 879-893.

Simanjuntak, L., Sriadhi, and Saragi, D. (2020). The Effect of Project Based Learning Models and Learning Motivation on Civics Learning Results in 4th Grade Primary School 106163 Percut Sei Tuan. Budapest International Research and Critics in Linguistics and Education (BirLE) Journal Vol 3 (3): 1509-1520.

Sudjana, Nana. (2009). Penilaian Hasil Proses Belajar Mengajar. Bandung: PT. Remaja Rosdakarya. 
Utami, P.S., and Gafur A. (2015). Pengaruh Metode Pembelajaran Dan Gaya Belajar Siswa Terhadap Hasil Belajar Ips Di Smp Negeri Di Kota Yogyakarta. Harmoni Sosial Jurnal Pendidikan IPS Volume 2, No 1, Maret 2015 PT. Remaja Rosdakarya. Utomo, M.R., et al. (2020). Influence of Problem Based Learning Models (PBL) and Learning Motivation to Learn Outcomes and Student's Critical Thinking Skills Themes of Caring for Life in Class IV Primary School No 026609 Pujidadi Binjai. Budapest International Research and Critics in Linguistics and Education (BirLE) Journal Vol 3 (4): 1634-1643. 